\title{
Diet and hair loss: effects of nutrient deficiency and supplement use
}

\author{
Emily L. Guo ${ }^{1}$, Rajani Katta ${ }^{2}$
}

1 Baylor College of Medicine, Houston, TX, USA

2 Department of Dermatology, Houston Methodist Hospital, Houston, TX, USA

Key words: hair loss, alopecia, diet, nutrition, supplementation

Citation: Guo EL, Katta R. Diet and hair loss: effects of nutrient deficiency and supplement use. Dermatol Pract Concept. 2017;7(1):1. DOI: http://dx.doi.org/10.5826/dpc.0701a01

Received: August 16, 2016; Accepted: November 25, 2016; Published: January 31, 2017

Copyright: $\odot 2017$ Guo et al. This is an open-access article distributed under the terms of the Creative Commons Attribution License, which permits unrestricted use, distribution, and reproduction in any medium, provided the original author and source are credited.

Funding: None.

Competing interests: The authors have no conflicts of interest to disclose.

All authors have contributed significantly to this publication.

Corresponding author: Rajani Katta, MD, 6800 West Loop South, Suite 180, Bellaire, TX 77401, USA. Tel. 281-501-3150; Fax. 832-8100072. Email: info@kattamd.com

ABSTRACT Patients presenting with hair loss should be screened by medical history, dietary history and physical exam for risk factors for nutrient deficiency. If warranted, laboratory studies may be performed. In patients with no risk factors, further laboratory evaluation searching for nutritional deficiencies is not warranted. For patients with nutritional deficiencies, it is clear that those deficiencies should be corrected. Further research is required to determine whether any benefit exists for nutrient supplementation in the absence of documented deficiency. At this time, patients must be informed that such research is lacking and that in fact some supplements carry the risk of worsening hair loss or the risk of toxicity.

\section{Introduction}

Patients with hair loss often inquire whether nutritional supplements can help restore hair growth or prevent further hair loss. In fact, many will start dietary supplements without consultation in the hope that the supplements will help. The unregulated supplement industry also capitalizes on this population's vulnerability. While hair follicles are among the most metabolically active in the body, and hair growth may be impacted by calorie and protein malnutrition as well as micronutrient deficiency, the links are complex.

Nutritional deficiency may impact both hair structure and hair growth. Effects on hair growth include acute telogen effluvium (TE), a well-known effect of sudden weight loss or decreased protein intake [1], as well as the diffuse alopecia seen in niacin deficiency [2]. Studies have also reported potential associations between nutritional deficiency and chronic TE, androgenetic alopecia (AGA), female pattern hair loss (FPHL), and alopecia areata (AA) [3,4].

Given this well-recognized link, many patients seeking treatment for hair loss ask about dietary recommendations. Specifically, is it necessary to test for nutrient deficiency in a patient presenting with hair loss? Are there risk factors that should prompt testing? In the absence of such risk factors, is there any evidence to support the use of micronutrient supplementation?

Physicians must be prepared to answer these questions. Hair loss is common, with close to $50 \%$ of men and women 
affected by pattern hair loss by age 50 [5]. Many nutritional supplements are marketed as hair loss treatments. A search of the keywords "hair loss" within the Vitamins \& Dietary Supplements section of Amazon.com, which sells supplements via Internet sales, yields 923 products [6]. Many are composed of differing formulations. The U.S. Food and Drug Administration (FDA) does not have the authority to review dietary supplements for safety and effectiveness before they are marketed, and it is therefore the responsibility of manufacturers [7].

Given the marketing efforts directed to consumers, physicians must be able to respond with a review of the known evidence. One point to emphasize is that such supplements are not without risks. In the absence of deficiency, supplementation may actually prove harmful to hair. Over-supplementation of certain nutrients, including selenium, Vitamin A, and Vitamin $\mathrm{E}$, has actually been linked to hair loss [4,8-11]. It is therefore surprising that the best-selling hair supplement on Amazon. com contains both vitamin A and vitamin E [12], while the next contains selenium, vitamin A, and vitamin E [13].

While such products contain a variety of nutrients, review of the medical literature finds a notable lack of evidence supporting their use. Much of what is known about nutrient effect on hair loss is based on disease states that result in deficiency. There is currently a lack of literature regarding the effects of supplementation in individuals without nutrient deficiency. In this paper, we review the available literature on nutrient deficiencies that result in hair loss, detail the risk factors for these deficiencies, and review the available evidence of the effects of supplementation, both beneficial and adverse, on hair loss.

\section{Iron}

Iron deficiency (ID) is the world's most common nutritional deficiency and is a well-known cause of hair loss. What remains unclear is what degree of ID may contribute to hair loss.

While the mechanism of action by which iron impacts hair growth is not known, hair follicle matrix cells are some of the most rapidly dividing cells in the body, and ID may contribute to hair loss via its role as a cofactor for ribonucleotide reductase, the rate-limiting enzyme for DNA synthesis [14]. In addition, multiple genes have been identified in the human hair follicle [15], and some may be regulated by iron [16]. In a mouse model, reversal of ID led to restoration of hair growth [17].

Certain populations are at higher risk for ID, and a medical and dietary history may reveal risk factors. Premenopausal women are at higher risk due to menstrual blood loss, while postmenopausal women and men may present due to gastrointestinal blood loss. Other risk factors include malabsorption disorders (such as celiac disease) as well as achlorhydria or the use of $\mathrm{H} 2$ blockers, as iron requires an acidic $\mathrm{pH}$ for absorption.
Vegans and vegetarians are also at higher risk for ID, as their requirements for dietary iron are considered to be 1.8 times higher than for meat consumers [18]. Non-heme iron, found in plants, has a lower bioavailability than heme iron, found in meat and fish [19].

Patients with more advanced ID develop iron deficiency anemia and require replacement. ID may also result in a reduction of storage iron, measured by serum ferritin. A normal ferritin level does not exclude ID, however, as it is an acute phase reactant.

Although multiple research studies have been conducted, it is unknown if a deficiency of storage iron contributes to hair loss, as conflicting results have been noted. Some studies have found that low serum ferritin is more prevalent in patients with chronic TE, FPHL, AGA, and AA. Other studies have found no such link. Two excellent review articles have summarized these results and note considerable variations in study design, controls, and ID definitions [16,20]. There are few intervention trials, and they are limited by small numbers, lack of controls in some, and variable ferritin levels. These have utilized different interventions, including iron alone [21], iron with L-lysine [8,22], and iron with spironolactone [23].

One study used a control population that excluded patients at risk for ID [24] and found no statistically significant increase in the prevalence of ID in premenopausal or postmenopausal women with chronic TE or FPHL.

At this time, there are no definitive answers. Patients must be approached on a case-by-case basis. In the aforementioned review articles, the researchers present their approach. Both groups test patients with iron studies, including serum ferritin. Both recommend treatment of ID, with or without anemia, with dietary sources and oral iron supplementation when necessary, with a goal of ferritin levels above $50 \mu \mathrm{g} / \mathrm{L}$ [16] or $70 \mu \mathrm{g} / \mathrm{ml}$, respectively [20].

Patients are monitored to measure their response-an important point. Patients who take iron supplements without monitoring are at risk for potentially severe complications, as iron supplementation leading to iron overload can cause toxicity. This can occur even at low levels if taken over a long period [25].

\section{Zinc}

Zinc is an essential mineral required by hundreds of enzymes and multiple transcription factors that regulate gene expression [26]. While the exact mechanism of action is unclear, one possibility centers on zinc's role as an essential component of numerous metalloenzymes important in protein synthesis and cell division [27]. Another possibility is zinc's role in the Hedgehog signaling pathway [28], a critical component in the pathways that govern hair follicle morphogenesis [29].

Zinc deficiency may be either inherited or acquired and 
may affect multiple organ systems. Patients may experience diarrhea, immunological effects, and delayed wound healing. Abnormalities in taste and smell may occur. Cutaneous effects include acral and periorificial dermatitis, while hair changes include TE and brittle hair.

The autosomal recessive disorder, acrodermatitis enteropathica, results in decreased absorption of zinc, while acquired zinc deficiency may occur in malabsorption syndromes, such as inflammatory bowel disease [30] or following gastric bypass surgery. Other groups at risk include patients with malignancy, those with liver or renal dysfunction, pregnant women [31], and patients with alcoholism [32]. Drugs that can affect zinc levels include valproic acid [33] and certain antihypertensives [34].

Dietary risk factors include vegetarianism, as bioavailability of zinc is lower in vegetables than meat [35]. Additionally, vegetarians typically consume more legumes and whole grains, which contain phytates that bind to zinc and inhibit absorption [35].

Serum zinc, the most commonly measured index of zinc status, may be impacted by several variables, and the functional effects of deficiency may be observed before serum levels decrease below normal [36].

Screening in those with risk factors is indicated, as hair loss due to zinc deficiency can be reversed. A case series demonstrated reversal of hair loss following oral supplementation in five patients with TE and zinc deficiency [37].

A study of 312 patients with AA, male pattern hair loss (MPHL), FPHL, or TE showed that all groups had statistically lower zinc concentrations as compared to 30 healthy controls [38]. In patients with AA and low serum zinc levels, supplementation has been shown to have therapeutic effects [39].

However, there is currently limited information on the effects of zinc supplementation on hair growth in those without documented deficiency. One report described a single patient with alopecia, without clear deficiency, who experienced improvement following oral zinc therapy [40].

A major point when considering supplementation in the absence of known deficiency is that zinc toxicity can occur with excess supplementation. Acute adverse effects include pain, vomiting, and diarrhea, while chronic effects include interaction with iron and reduced immune function [18].

\section{Niacin}

Pellagra, due to a deficiency of niacin, results in the wellknown triad of photosensitive dermatitis, diarrhea, and dementia. Alopecia is another frequent clinical finding [2].

Pellagra became rare in many developed countries after niacin fortification of food was introduced. Alcoholism is now considered the most common cause of pellagra in developed countries [41]. Other causes include malabsorption disorders or drug-induced cases, such as with isoniazid [41].
In a review of the literature, no studies regarding niacin levels in patients presenting only with hair loss were identified.

\section{Fatty Acids}

Deficiency of the polyunsaturated essential fatty acids linoleic acid (an omega-6 fatty acid) and alpha-linolenic acid (an omega-3 fatty acid) can result from inappropriate parenteral nutrition and malabsorption disorders such as cystic fibrosis. Hair changes include loss of scalp hair and eyebrows as well as lightening of hair $[3,4]$. Unsaturated fatty acids may modulate androgen action by inhibition of $5 a$-reductase, similar to the drug finasteride [42]. Additionally, arachidonic acid, an omega-6 fatty acid, may promote hair growth by enhancing follicle proliferation [43].

However, limited information is available on supplementation. In one patient with essential fatty acid deficiency, topical application of safflower oil, high in linoleic acid, resulted in growth of hair [44].

While results from a trial utilizing a supplement were reported, limited conclusions may be drawn, as this supplement combined multiple fatty acids and antioxidants [45].

\section{Selenium}

Selenium is an essential trace element that plays a role in protection from oxidative damage as well as hair follicle morphogenesis. Rats deficient in selenium display sparse hair growth [46], while knockout mice lacking specific selenoproteins exhibit progressive hair loss after birth [47].

Risk factors for deficiency include living in areas with low selenium soil content (particularly in parts of China, Tibet, and Siberia), long-term hemodialysis, HIV, and malabsorption disorders [48].

There is limited research on selenium deficiency and alopecia in humans. One case report in a child described sparse hair, which improved after dietary supplementation [49].

Given the lack of human research, it is surprising that some hair loss supplements are marketed as containing selenium. This is concerning, as selenium toxicity from nutritional supplementation is well documented [9-11]. Toxicity can result in generalized hair loss, as well as blistering skin lesions, gastrointestinal symptoms, and memory difficulties.

\section{Vitamin D}

Data from animal studies suggests that vitamin D plays a role in hair follicle cycling [50]. In a study of mice treated to model vitamin D-dependent rickets, the resultant animals developed hair loss [51]. In vitro studies have shown increase in vitamin $\mathrm{D}$ receptor expression in the outer root sheath keratinocytes during the growing phases of the hair cycle [52]. 
Risk factors for vitamin D deficiency include inadequate sun exposure, dark skin, obesity, gastric bypass, and fat malabsorption [53].

One study of eight females with TE or FPHL showed that serum vitamin D2 levels were significantly lower than in controls. Furthermore, vitamin D2 levels decreased with increased disease severity [54]. However, data on the effects of vitamin D supplementation in hair loss is lacking.

\section{Vitamin A}

Vitamin A is a group of compounds including retinol, retinal, retinoic acid, and provitamin A carotenoids. In murine studies, dietary vitamin A has been shown to activate hair follicle stem cells [55], although its role is recognized as complex and "precise levels of retinoic acid are needed for optimal function of the hair follicle" [56].

While deficiency has not been linked to hair loss, high levels of vitamin A have. In fact, one study found that in a mouse AA model, reduction of vitamin A in the diet actually delayed hair loss onset [56].

In humans, hypervitaminosis A may result from oversupplementation and has a strong known link to hair loss with other effects such as skin, vision, and bone changes $[4,8]$.

\section{Vitamin E}

Tocotrienols and tocopherols are members of the vitamin E family and are potent antioxidants. Deficiency results in hemolytic anemias, neurologic findings, and skin dryness. Vitamin E deficiency is rare, but may occur with fat malabsorption disorders.

Minimal information in the literature exists regarding benefits of vitamin E supplementation on hair loss. One study of 21 volunteers who received tocotrienol supplementation (100 mg of mixed tocotrienols daily) showed significant increase in hair number as compared to a placebo group [57].

However, excess supplementation may result in hypervitaminosis $\mathrm{E}$, which can increase the risk of bleeding and decrease thyroid hormone production. Additionally, there is some evidence for an adverse effect on hair growth, as seen in volunteers taking 600 IU per day for 28 days, a dosage around 30 times the daily recommended intake [8]. This group had significant decreases in thyroid hormone levels [8].

\section{Folic Acid}

Folic acid is found in leafy greens and many foods are fortified with folic acid, making deficiency uncommon. Deficiency mainly results in megaloblastic anemia, without manifestation of hair loss.
No significant difference in serum folate levels was seen in 91 patients with diffuse hair loss as compared to controls [58]. In fact, another study of 200 women with chronic TE showed $28.5 \%$ had elevated serum folic acid, although methodology of the study was not included and therefore limited conclusions may be drawn [8].

\section{Biotin}

Biotin, or vitamin $\mathrm{H}$, serves as a cofactor for carboxylation enzymes. In isolated sheep hair follicles, incubation in biotincontaining solutions resulted in increased DNA concentration and protein synthesis [59].

Symptoms of deficiency include eczematous skin rash, alopecia, and conjunctivitis [60]. One study of an infant fed with a formula lacking sufficient biotin content reported manifestations of periorificial dermatitis and patchy alopecia, both of which resolved with daily oral supplementation of biotin [61].

Biotin deficiency is rare, as intestinal bacteria are typically able to produce adequate levels of biotin. Deficiency is seen in cases of congenital or acquired biotinidase or carboxylase deficiency, antibiotic use disrupting the gastrointestinal flora, and antiepileptic use. Deficiency can occur from excessive ingestion of raw egg whites due to binding by avidin.

No clinical trials have shown efficacy in treating hair loss with biotin supplementation in the absence of deficiency. Despite this, biotin is found in multiple supplements marketed to consumers for hair loss. This marketing approach may have been chosen as biotin has shown positive effects in the treatment of brittle fingernails and onychoschizia [62-63].

\section{Amino Acids and Proteins}

Protein malnutrition, such as in kwashiorkor and marasmus, can result in hair changes that include hair thinning and hair loss [64].

One study examined the role of L-lysine, an essential amino acid that may play a role in iron and zinc uptake. Addition of L-lysine to iron supplementation resulted in a significant increase in mean serum ferritin concentration in some women with chronic TE who failed to respond to iron supplementation alone [8]. Although interesting, there is limited data available, and the role of L-lysine should be investigated further.

In terms of other amino acids and proteins, no clear conclusions may be drawn about the role of supplementation in hair loss. While trials of amino acid and protein supplements have been published, they are formulated with a variety of nutrients, and therefore it is unclear what role, if any, is played by amino acid and protein supplementation in the absence of known deficiency. 
TABLE 1. Effects of nutrient deficiency and supplement use on hair loss. [Copyright: @2017 Guo et al.]

\begin{tabular}{|c|c|c|}
\hline Nutrient & Effect of Deficiency on Hair Loss & Studies of Supplementation \\
\hline Iron & $\begin{array}{l}\text { - Chronic diffuse telogen hair loss with iron } \\
\text { deficiency anemia [20]. } \\
\text { - In the absence of anemia, studies are not clear } \\
\text { whether there is a significant link between ID } \\
\text { and hair loss }[16,20,24] \text {. }\end{array}$ & $\begin{array}{l}\text { - Insufficient evidence to recommend iron } \\
\text { supplementation to all hair loss patients with } \\
\text { iron deficiency in the absence of anemia [20]. } \\
\text { Approach on a case-by-case basis. } \\
\text { - Excess supplementation can cause } \\
\text { hemochromatosis [25]. }\end{array}$ \\
\hline Zinc & $\begin{array}{l}\text { - Statistically lower serum zinc concentrations } \\
\text { in a study of } 312 \text { patients with AA, MPHL, } \\
\text { FPHL, or TE compared to } 30 \text { healthy controls } \\
\text { [38]. }\end{array}$ & $\begin{array}{l}\text { - A case series demonstrated reversal of hair } \\
\text { loss following oral supplementation in five } \\
\text { patients with TE and zinc deficiency [37]. } \\
\text { - Limited information on effects of zinc } \\
\text { supplementation improving hair growth in the } \\
\text { absence of deficiency. } \\
\text { - One case report with a patient with dry } \\
\text { brittle hair and alopecia, without clear zinc } \\
\text { deficiency, who experienced improvement in } \\
\text { alopecia following oral zinc therapy [40]. } \\
\text { Excess supplementation can cause acute toxic } \\
\text { effects including epigastric pain, nausea, } \\
\text { vomiting diarrhea, and headache and chronic } \\
\text { toxic effects including reduced copper status, } \\
\text { interaction with iron, reduced immune } \\
\text { function, and decreased concentrations of } \\
\text { HDL cholesterol [18]. }\end{array}$ \\
\hline Niacin (Vitamin B3) & $\begin{array}{l}\text { - Diffuse hair loss with pellagra due to severe } \\
\text { deficiency [2]. } \\
\text { - No known studies regarding serum niacin } \\
\text { levels in patients with hair loss. }\end{array}$ & $\begin{array}{l}\text { - Limited information on effects of niacin } \\
\text { supplementation improving hair growth in } \\
\text { absence of deficiency. }\end{array}$ \\
\hline Fatty acids & - Loss of scalp and eyebrow hair [3-4]. & $\begin{array}{l}\text { - Limited information on effects of fatty acid } \\
\text { supplementation improving hair growth in } \\
\text { absence of deficiency. }\end{array}$ \\
\hline Selenium & $\begin{array}{l}\text { - In animal studies, rats deficient in selenium } \\
\text { display sparse hair growth [46], while } \\
\text { knockout mice lacking specific selenoproteins } \\
\text { exhibit progressive hair loss after birth, } \\
\text { ultimately leading to almost total alopecia } \\
\text { [47]. } \\
\text { - One case report of selenium deficiency in a } \\
\text { young child reported clinical manifestations } \\
\text { of dry skin and sparse, light-colored hair, } \\
\text { improving after supplementation [49]. }\end{array}$ & $\begin{array}{l}\text { - Limited information on effects of selenium } \\
\text { supplementation improving hair growth in } \\
\text { absence of deficiency. } \\
\text { - Toxicity from excess supplementation is well } \\
\text { documented and can cause generalized hair } \\
\text { loss [9-11]. }\end{array}$ \\
\hline Vitamin D & $\begin{array}{l}\text { - Serum vitamin D2 levels in a study of eight } \\
\text { females with either TE or FPHL were shown } \\
\text { to be significantly lower than in } 40 \text { age- } \\
\text { matched female controls, with decreased levels } \\
\text { correlating to increased disease severity [54]. }\end{array}$ & $\begin{array}{l}\text { - Limited information on effects of vitamin D } \\
\text { supplementation improving hair growth in } \\
\text { absence of deficiency. }\end{array}$ \\
\hline Vitamin A & - Deficiency has no known link to hair loss. & $\begin{array}{l}\text { - Limited information on effects of vitamin A } \\
\text { supplementation improving hair growth in } \\
\text { absence of deficiency. } \\
\text { - Toxicity from excess supplementation has } \\
\text { a strong known link to hair loss, as well as } \\
\text { other effects on skin, vision, and bone }[4,8] \text {. }\end{array}$ \\
\hline
\end{tabular}

(Continued next page) 
TABLE 1. (continued)

\begin{tabular}{|c|c|c|}
\hline Nutrient & Effect of Deficiency on Hair Loss & Studies of Supplementation \\
\hline Vitamin E & - Deficiency has no known link to hair loss. & $\begin{array}{l}\text { - Limited information on effects of vitamin E } \\
\text { supplementation improving hair growth in } \\
\text { absence of deficiency. } \\
\text { - Supplementation in one study of twenty-one } \\
\text { volunteers suffering from hair loss has showed } \\
\text { significant increase in hair number compared } \\
\text { to placebo [57]. } \\
\text { - Toxicity from excess supplementation can } \\
\text { result in risk of bleeding problems, decreased } \\
\text { thyroid hormones, and decreased activity of } \\
\text { vitamin K. Additionally, there is some evidence } \\
\text { for adverse effect on hair growth with excess } \\
\text { supplementation [8]. }\end{array}$ \\
\hline Folic Acid & $\begin{array}{l}\text { - No significant difference in serum folate levels } \\
\text { in a study of } 91 \text { patients with diffuse hair loss } \\
\text { and } 74 \text { healthy controls [58]. }\end{array}$ & $\begin{array}{l}\text { - Limited information on effects of folic acid } \\
\text { supplementation improving hair growth in } \\
\text { absence of deficiency. }\end{array}$ \\
\hline Biotin & $\begin{array}{l}\text { Deficiency can result in alopecia, eczematous } \\
\text { skin rash, conjunctivitis, and candidiasis [60]. }\end{array}$ & $\begin{array}{l}\text { - Limited information on effects of biotin } \\
\text { supplementation improving hair growth in } \\
\text { absence of deficiency. }\end{array}$ \\
\hline $\begin{array}{l}\text { Amino Acids and } \\
\text { Proteins }\end{array}$ & $\begin{array}{l}\text { - Protein malnutrition can result in hair loss } \\
\text { [64]. }\end{array}$ & $\begin{array}{l}\text { - L-lysine supplementation in addition to } \\
\text { iron supplementation has been shown to } \\
\text { significantly increase mean serum ferritin } \\
\text { concentration in some women with } \\
\text { chronic TE who failed to respond to iron } \\
\text { supplementation alone [8]. } \\
\text { - Limited information on effects other amino } \\
\text { acids and proteins improving hair growth in } \\
\text { absence of deficiency. }\end{array}$ \\
\hline
\end{tabular}

Key of abbreviations: Alopecia areata - AA; Androgenic alopecia - AGA; Female pattern hair loss - FPHL; High density lipoprotein - HDL; Iron deficiency - ID; Male pattern hair loss - MPHL; Telogen effluvium - TE.

One trial included L-cysteine, a constituent of keratin, in combination with medicinal yeast and pantothenic acid [65]. Other trials have evaluated supplements containing marine proteins in conjunction with multiple other nutrients [66-69]. However, it is difficult to evaluate the results of these trials, as the composition of these nutritional supplements is not disclosed. Marketing materials accessed from one product's website describe the composition as including "vitamins and minerals for hair growth, including iron, zinc, biotin, niacin, vitamin $\mathrm{C}$ and an exclusive marine complex derived from fish proteins" [70].

\section{Antioxidants}

Antioxidants are compounds that are able to neutralize reactive oxygen species (ROS), preventing oxidative damage. Many substances can be classified as antioxidants, including zinc, selenium, and vitamins $\mathrm{A}$ and $\mathrm{E}$, as described previously in this article, as well as vitamin $\mathrm{C}$ and polyphenols [71]. Oxidative stress has been linked to hair loss. In vitro studies of dermal papilla cells from male AGA patients have shown that oxidative stress may have an important role in the balding phenotype and development of AGA [72]. Additionally, in a study of endogenous antioxidant enzymes and lipid peroxidation in the scalps of patients with AA, excessive free radical generation was shown to occur in the scalps of patients with AA accompanied by high levels of antioxidant enzymes that were unable to protect against the ROS [73].

While dietary antioxidants play a key role in reinforcing our endogenous antioxidant system, high doses of exogenous antioxidants may actually disrupt the balance between oxidation and antioxidation [71]. In vitro studies have shown that while polyphenols have antioxidant properties at low concentrations, they can potentiate ROS generation at higher concentrations [71, 74-75]. Compounds within plant foods, such as from fruits, vegetables, and grains, may be safer and healthier compared to isolated, high doses present in supplements [71].

\section{Conclusion}

While multiple nutrient deficiencies may result in hair loss (Table 1), screening for such deficiencies must be guided by the 
TABLE 2. Medical and dietary history risk factors that can cause nutritional deficiencies contributing to hair loss. [Copyright: (C2017 Guo et al.]

\begin{tabular}{|l|l|}
\hline \multicolumn{1}{|c|}{ Medical or Dietary History Risk Factor } & \multicolumn{1}{c|}{ Nutrient Deficiency } \\
\hline $\begin{array}{l}\text { History of blood loss (menstrual in } \\
\text { premenopausal women, GI in postmenopausal } \\
\text { women and men) }\end{array}$ & Iron \\
\hline Malabsorption disorders & Multiple vitamin deficiencies \\
\hline Pregnancy & Iron, folic acid, zinc \\
\hline Alcoholism & Folic acid, zinc, niacin \\
\hline Malignancy & Iron, zinc, can depend on type of malignancy \\
\hline Renal dysfunction & Selenium, zinc \\
\hline H2 blocker use & Iron \\
\hline Antiepileptics & Biotin, Zinc \\
\hline Antihypertensives & Zinc \\
\hline Prolonged antibiotic use & Biotin \\
\hline Isoniazid & Niacin \\
\hline Inadequate sun exposure & Vitamin D \\
\hline Living in parts of China, Tibet, and Siberia & Selenium \\
\hline Vegans/vegetarians & Iron, zinc \\
\hline Excessive ingestion of raw egg whites & Biotin \\
\hline Malnutrition & Multiple vitamin deficiencies \\
\hline
\end{tabular}

history and physical exam. Nutrient deficiencies may arise due to genetic disorders, medical conditions, or dietary practices.

If risk factors are identified (Table 2), then laboratory screening for nutrient deficiency may be indicated. In patients with hair loss, but without any known risk factors for nutrient deficiency, laboratory testing for nutrient deficiency is not required.

An area that requires further research is the role of supplementation. It is clear that nutrient deficiencies must be corrected. What is unclear is the ideal range of micronutrient levels to prevent or correct hair loss. In ID and anemia, supplementation is required, but patients with ID in the absence of anemia must be approached on a case-by-case basis. Some authors believe that raising levels of storage iron may improve hair loss, although the research is not conclusive. All patients receiving iron supplementation must be monitored due to toxicity risk.

For other nutrients, such as zinc, supplementation in deficient patients has resulted in hair growth, although, again, patients must be monitored due to toxicity risk (Table 3 ).

There is very limited research on the role of nutrient supplementation in the absence of deficiency. Despite this, patients often seek nutrient supplements as a treatment for hair loss. In fact, direct-to-consumer advertising promotes the use of supplements for hair loss, and many such products, containing a wide variety of formulations, are easily available for purchase.
TABLE 3. Potential toxicities of supplements. [Copyright: (C2017 Guo et al.]

\begin{tabular}{|c|c|}
\hline $\begin{array}{l}\text { Supplement } \\
\text { in Excess }\end{array}$ & Signs and Symptoms of Toxicity \\
\hline Iron & $\begin{array}{l}\text { Acute } \\
\text { - GI bleeding } \\
\text { - Abdominal pain } \\
\text { - Metabolic acidosis } \\
\text { Chronic } \\
\text { - Hemochromatosis }\end{array}$ \\
\hline Zinc & $\begin{array}{l}\text { Acute } \\
\text { - Abdominal pain } \\
\text { - Vomiting } \\
\text { - Diarrhea } \\
\text { Chronic } \\
\text { - Interaction with iron } \\
\text { - Immune dysfunction }\end{array}$ \\
\hline Selenium & $\begin{array}{l}\text { - Hair loss } \\
\text { - Blistering skin lesions } \\
\text { - Gastrointestinal symptoms } \\
\text { - Memory difficulties } \\
\end{array}$ \\
\hline Vitamin A & $\begin{array}{l}\text { - Hair loss } \\
\text { - Skin, vision, and bone changes } \\
\text { - Increased intracranial pressure }\end{array}$ \\
\hline Vitamin E & $\begin{array}{l}\text { - Increased risk of bleeding } \\
\text { - Decreased thyroid hormone } \\
\text { production } \\
\text { - Possible adverse effect on hair growth }\end{array}$ \\
\hline
\end{tabular}


Physicians must counsel their patients on the lack of research supporting these products. Since supplements are not regulated by the FDA, it is up to the physician and the consumer to review the efficacy and safety of supplements. Websites such as the Natural Medicines Comprehensive Database [76] or the National Institutes of Health Office of Dietary Supplements' PubMed Dietary Supplement Subset [77] and Dietary Supplements Ingredient Database [78] may be of help in this exploration. Equally important is a discussion of the potential toxicity of some of these supplements. Over-supplementation of some nutrients may result in multiple toxicities, while over-supplementation of certain nutrients, including vitamin $\mathrm{A}$, vitamin $\mathrm{E}$, and selenium, may actually result in hair loss.

\section{References}

1. Mubki T, Rudnicka L, Olszewska M, Shapiro J. Evaluation and diagnosis of the hair loss patient: part I. History and clinical examination. J Am Acad Dermatol. 2014;71(3):415.e1-e415.e15.

2. Spivak JL, Jackson DL. Pellagra: an analysis of 18 patients and a review of the literature. Johns Hopkins Med J. 1977;140(6):295309.

3. Goldberg LJ, Lenzy Y. Nutrition and hair. Clin Dermatol. 2010;28 (4):412-419.

4. Finner AM. Nutrition and hair: deficiencies and supplements. Dermatol Clin. 2013;31(1):167-172.

5. Rogers NE, Avram MR. Medical treatments for male and female pattern hair loss. J Am Acad Dermatol. 2008;59(4):547-566.

6. Amazon.com: Hair Loss - Vitamins \& Dietary Supplements: Health \& Household. Amazon.com website. https://www.amazon. com/s/ref=nb_sb_noss_2 ?url=node\%3D3764441\&field-key words=hair+loss. Accessed May 16, 2016.

7. Dietary Supplements: What You Need to Know. U.S. Food and Drug Administration website. http://www.fda.gov/Food/Dietary Supplements/UsingDietarySupplements/ucm109760.htm. Updated January 6, 2016. Accessed August 4, 2016.

8. Rushton DH. Nutritional factors and hair loss. Clin Exp Dermatol. 2002;27(5):396-404.

9. Aldosary BM, Sutter ME, Schwartz M, Morgan BW. Case series of selenium toxicity from a nutritional supplement. Clin Toxicol (Phila). 2012;50(1):57-64.

10. Lopez RE, Knable AL, Burruss JB. Ingestion of a dietary supplement resulting in selenium toxicity. J Am Acad Dermatol. 2010;63(1):168-169.

11. Srivastava AK, Gupta BN, Bihari V, Gaur JS. Generalized hair loss and selenium exposure. Vet Hum Toxicol. 1995;37(5):468-469.

12. Amazon.com: SugarBearHair Vitamins (1 Month Supply). Amazon.com website. http://www.amazon.com/SugarBearHair-Vita mins-1-Month-Supply/dp/B019ZZB3O2/ref=sr_1_1_s_it?s=hpc \&ie=UTF8\&qid=1463609554\&sr=1-1. Accessed May 16, 2016.

13. Amazon.com: Hair Growth Essentials: \#1 Rated Hair Loss Supplement for Women and Men - Advanced Hair Regrowth Treatment With 29 Powerful Hair Growth Vitamins \& Nutrients for Rapid Growth - 30 Day Supply. Amazon.com website. http://www.amazon.com/Hair-Growth-Essentials-SupplementTreatment/dp/B00MMA7W5C/ref=sr_1_3_s_it?s=hpc\&ie=UTF 8\&qid=1463609554\&sr=1-3. Accessed May 16, 2016.
14. Kantor J, Kessler LJ, Brooks DG, Cotsarelis G. Decreased serum ferritin is associated with alopecia in women.J Invest Dermatol. 2003;121(5):985-988.

15. Ohyama M, Terunuma A, Tock CL, et al. Characterization and isolation of stem cell-enriched human hair follicle bulge cells. $J$ Clin Invest. 2006;116(1):249-260.

16. St Pierre SA, Vercellotti GM, Donovan JC, Hordinsky MK. Iron deficiency and diffuse nonscarring scalp alopecia in women: more pieces to the puzzle. J Am Acad Dermatol. 2010;63(6):1070-1076.

17. Du X, She E, Gelbart T, et al. The serine protease TMPRSS6 is required to sense iron deficiency. Science. 2008;320(5879):10881092.

18. Institute of Medicine (US) Panel on Micronutrients. Dietary Reference Intakes for Vitamin A, Vitamin K, Arsenic, Boron, Chromium, Copper, Iodine, Iron, Manganese, Molybdenum, Nickel, Silicon, Vanadium, and Zinc. Washington (DC): National Academy Press (US); 2001.

19. Camaschella C, Schrier SL. Regulation of iron balance. UpToDate website. www.UpToDate.com. Updated November 11, 2015. Accessed June 27, 2016.

20. Trost LB, Bergfeld WF, Calogeras E. The diagnosis and treatment of iron deficiency and its potential relationship to hair loss. J Am Acad Dermatol. 2006;54(5):824-844.

21. Hard S. Non-anemia iron deficiency as an etiologic factor in diffuse loss of hair of the scalp in women. Acta Derm Venereol. 1963;43:562-569.

22. Rushton DH, Norris MJ, Dover R, Busuttil N. Causes of hair loss and the developments in hair rejuvenation. Int J Cosmet Sci. 2002;24(1):17-23.

23. Sinclair R. There is no clear association between low serum ferritin and chronic diffuse telogen hair loss. Br J Dermatol. 2002;147(5):982-984.

24. Olsen EA, Reed KB, Cacchio PB, Caudill L. Iron deficiency in female pattern hair loss, chronic telogen effluvium, and control groups. J Am Acad Dermatol. 2010;63(6):991-999.

25. Coates TD, Carson S, Wood JC, Berdoukas V. Management of iron overload in hemoglobinopathies: what is the appropriate target iron level? Ann N Y Acad Sci. 2016;1368(1):95-106.

26. Ogawa Y, Kawamura T, Shimada S. Zinc and skin biology. Arch Biochem Biophys. [Epub June 2016].

27. MacDonald RS. The role of zinc in growth and cell proliferation. J Nutr. 2000;130(5S Suppl):1500S-8S.

28. Ruiz i Altaba A. Gli proteins and Hedgehog signaling: development and cancer. Trends Genet. 1999;15(10):418-425.

29. St-Jacques B, Dassule HR, Karavanova I, et al. Sonic hedgehog signaling is essential for hair development. Curr Biol. 1998;8 (19):1058-1068.

30. Valberg LS, Flanagan PR, Kertesz A, Bondy DC. Zinc absorption in inflammatory bowel disease. Dig Dis Sci. 1986;31(7):724-731. PMID: 2873002.

31. Caulfield LE, Zavaleta N, Shankar AH, Merialdi M. Potential contribution of maternal zinc supplementation during pregnancy to maternal and child survival. Am J Clin Nutr. 1998;68(2 Suppl):499S-508S.

32. Dinsmore W, Callender ME, McMaster D, Todd SJ, Love AH. Zinc absorption in alcoholics using zinc-65. Digestion. 1985;32(4):238-242.

33. Yilmaz Y, Tasdemir HA, Paksu MS. The influence of valproic acid treatment on hair and serum zinc levels and serum biotinidase activity. Eur J Paediatr Neurol. 2009;13(5):439-443. 
34. Braun LA, Rosenfeldt F. Pharmaco-nutrient interactions-a systematic review of zinc and antihypertensive therapy. Int J Clin Pract. 2013;67(8):717-725.

35. Hunt JR. Bioavailability of iron, zinc, and other trace minerals from vegetarian diets. Am J Clin Nutr. 2003;78(3 Suppl):633S639S.

36. Maret W, Sandstead HH. Zinc requirements and the risks and benefits of zinc supplementation. J Trace Elem Med Biol. 2006;20(1):3-18.

37. Karashima T, Tsuruta D, Hamada T, et al. Oral zinc therapy for zinc deficiency-related telogen effluvium. Dermatol Ther. 2012;25(2):210-213.

38. Kil MS, Kim CW, Kim SS. Analysis of serum zinc and copper concentrations in hair loss. Ann Dermatol. 2013;25(4):405409. PMID: 24371385. DOI: http://dx.doi.org/10.5021/ ad.2013.25.4.405.

39. Park H, Kim CW, Kim SS, Park CW. The therapeutic effect and the changed serum zinc level after zinc supplementation in alopecia areata patients who had a low serum zinc level. Ann Dermatol. 2009;21(2):142-146

40. Slonim AE, Sadick N, Pugliese M, Meyers-Seifer CH. Clinical response of alopecia, trichorrhexis nodosa, and dry, scaly skin to zinc supplementation. J Pediatr. 1992;121(6):890-895.

41. Wan P, Moat S, Anstey A. Pellagra: a review with emphasis on photosensitivity. Br J Dermatol. 2011;164(6):1188-1200. PMID: 21128910. DOI: http://dx.doi.org/10.1111/j.1365-2133. 2010.10163.x.

42. Liang $T$, Liao $S$. Inhibition of steroid 5 alpha-reductase by specific aliphatic unsaturated fatty acids. Biochem J. 1992;285(Pt 2):557562.

43. Munkhbayar S, Jang S, Cho A-R, et al. Role of arachidonic acid in promoting hair growth. Ann Dermatol. 2016;28(1):55-64.

44. Skolnik P, Eaglstein WH, Ziboh VA. Human essential fatty acid deficiency: treatment by topical application of linoleic acid. Arch Dermatol. 1977;113(7):939-941.

45. Le Floc'h C, Cheniti A, Connétable S, Piccardi N, Vincenzi C, Tosti A. Effect of a nutritional supplement on hair loss in women. J Cosmet Dermatol. 2015;14(1):76-82.

46. Bates JM, Spate VL, Morris JS, St Germain DL, Galton VA. Effects of selenium deficiency on tissue selenium content, deiodinase activity, and thyroid hormone economy in the rat during development. Endocrinology. 2000;141(7):2490-2500.

47. Sengupta A, Lichti UF, Carlson BA, et al. Selenoproteins are essential for proper keratinocyte function and skin development. PLoS ONE. 2010;5(8):e12249.

48. Selenium Dietary Supplement Fact Sheet. National Institutes of Health Office of Dietary Supplements website. https://ods.od.nih. gov/factsheets/Selenium-HealthProfessional/. Updated February 11, 2016. Accessed July 5, 2016.

49. Kanekura T, Yotsumoto S, Maeno N, et al. Selenium deficiency: report of a case. Clin Exp Dermatol. 2005;30(4):346-348.

50. Amor KT, Rashid RM, Mirmirani P. Does D matter? The role of vitamin $\mathrm{D}$ in hair disorders and hair follicle cycling. Dermatol Online J. 2010;16(2):3.

51. Li YC, Pirro AE, Amling M, et al. Targeted ablation of the vitamin D receptor: an animal model of vitamin D-dependent rickets type II with alopecia. Proc Natl Acad Sci USA. 1997;94(18):98319835.

52. Reichrath J, Schilli M, Kerber A, Bahmer FA, Czarnetzki BM, Paus R. Hair follicle expression of 1,25-dihydroxyvitamin D3 receptors during the murine hair cycle. Br J Dermatol. 1994;131(4):477482.

53. Vitamin D Fact Sheet for Health Professionals. National Institutes of Health Office of Dietary Supplements website https://ods. od.nih.gov/factsheets/VitaminD-HealthProfessional/. Updated February 11, 2016. Accessed July 5, 2016.

54. Rasheed H, Mahgoub D, Hegazy R, et al. Serum ferritin and vitamin $\mathrm{d}$ in female hair loss: do they play a role? Skin Pharmacol Physiol. 2013;26(2):101-107.

55. Suo L, Sundberg JP, Everts HB. Dietary vitamin A regulates wingless-related MMTV integration site signaling to alter the hair cycle. Exp Biol Med (Maywood). 2015;240(5):618-623.

56. Everts $\mathrm{HB}$. Endogenous retinoids in the hair follicle and sebaceous gland. Biochim Biophys Acta. 2012;1821(1):222-229.

57. Beoy LA, Woei WJ, Hay YK. Effects of tocotrienol supplementation on hair growth in human volunteers. Trop Life Sci Res. 2010;21(2):91-99.

58. Durusoy C, Ozenli Y, Adiguzel A, et al. The role of psychological factors and serum zinc, folate and vitamin B12 levels in the aetiology of trichodynia: a case-control study. Clin Exp Dermatol. 2009;34(7):789-792.

59. Galbraith H. In vitro methodology, hormonal and nutritional effects and fibre production in isolated ovine and caprine anagen hair follicles. Animal. 2010;4(9):1482-1489.

60. Wolf B. Biotinidase Deficiency. In: Pagon RA, Adam MP, Ardinger $\mathrm{HH}$, et al., eds. GeneReviews ${ }^{\circledR}$. Seattle (WA): University of Washington, Seattle; 1993. http://www.ncbi.nlm.nih.gov/books/ NBK1322/. Accessed July 4, 2016.

61. Fujimoto W, Inaoki M, Fukui T, Inoue Y, Kuhara T. Biotin deficiency in an infant fed with amino acid formula. $J$ Dermatol. 2005;32(4):256-261. PMID: 15863846. DOI: http://dx.doi. org/10.1111/j.1346-8138.2005.tb00758.x.

62. Rogers NE, Avram MR. Medical treatments for male and female pattern hair loss. J Am Acad Dermatol. 2008;59(4):547-566; quiz 567-8.

63. Colombo VE, Gerber F, Bronhofer M, Floersheim GL. Treatment of brittle fingernails and onychoschizia with biotin: scanning electron microscopy. J Am Acad Dermatol. 1990;23(6 Pt 1):11271132.

64. McLaren DS. Skin in protein energy malnutrition. Arch Dermatol. 1987;123(12):1674-1676a.

65. Lengg N, Heidecker B, Seifert B, Trüeb RM. Dietary supplement increases anagen hair rate in women with telogen effluvium: results of a double-blind, placebo-controlled trial. Therapy. 2007;4 (1):59-65

66. Ablon G. A double-blind, placebo-controlled study evaluating the efficacy of an oral supplement in women with self-perceived thinning hair. J Clin Aesthet Dermatol. 2012;5(11):28-34.

67. Ablon G. A 3-month, randomized, double-blind, placebo-controlled study evaluating the ability of an extra-strength marine protein supplement to promote hair growth and decrease shedding in women with self-perceived thinning hair. Dermatol Res Pract. 2015;2015:841570.

68. Thom E. Efficacy and tolerability of Hairgain in individuals with hair loss: a placebo-controlled, double-blind study. I Int Med Res. 2001;29(1):2-6

69. Rizer RL, Stephens TJ, Herndon JH, Sperber BR, Murphy J, Ablon GR. A marine protein-based dietary supplement for subclinical hair thinning/loss: results of a multisite, double-blind, placebocontrolled clinical trial. Int J Trichology. 2015;7(4):156-166. 
70. Vitamins and Minerals for Healthier Hair. Viviscal website. http:// www.viviscal.com/vitamins-and-minerals-for-healthier-hair. Accessed June 2, 2016.

71. Bouayed J, Bohn T. Exogenous antioxidants-double-edged swords in cellular redox state: Health beneficial effects at physiologic doses versus deleterious effects at high doses. Oxid Med Cell Longev. 2010;3(4):228-237.

72. Upton JH, Hannen RF, Bahta AW, Farjo N, Farjo B, Philpott MP. Oxidative stress-associated senescence in dermal papilla cells of men with androgenetic alopecia. J Invest Dermatol. 2015;135(5):1244-1252.

73. Akar A, Arca E, Erbil H, Akay C, Sayal A, Gür AR. Antioxidant enzymes and lipid peroxidation in the scalp of patients with alopecia areata. J Dermatol Sci. 2002;29(2):85-90.

74. De Marchi U, Biasutto L, Garbisa S, Toninello A, Zoratti M. Quercetin can act either as an inhibitor or an inducer of the mitochondrial permeability transition pore: a demonstration of the ambivalent redox character of polyphenols. Biochim Biophys Acta. 2009;1787(12):1425-1432.

75. Wätjen W, Michels G, Steffan B, et al. Low concentrations of flavonoids are protective in rat H4IIE cells whereas high concentrations cause DNA damage and apoptosis. J Nutr. 2005;135(3):525-531.

76. Natural Medicines Comprehensive Database website. http:// naturaldatabase.therapeuticresearch.com. Accessed November 7, 2016.

77. PubMed Dietary Supplement Subset. National Institutes of Health Office of Dietary Supplements website. https://ods.od.nih.gov/ Research/PubMed_Dietary_Supplement_Subset.aspx. Accessed November 7, 2016.

78. Dietary Supplements Ingredient Database. National Institutes of Health Office of Dietary Supplements website. https://dietarysupplementdatabase.usda.nih.gov/. Accessed November 7, 2016. 
